\title{
A War of Minds Waged Against Bodies: The Political Activist as Prisoner and Patient
}

\author{
Anna Hinton \\ Rutgers University, US \\ ah1087@english.rutgers.edu
}

In disability studies, discussing the process of becoming disabled is often discouraged. It is not ok to ask "what happened" because it positions disability as an accident and otherwise undesirable. Instead, the field has focused on the social model as a way to divorce disability from discourses about suffering, and rightly so, affirm disabled identity while challenging social societal attitudes that devalue disabled life and obstacles such as environments inhospitable to disabled bodies. Despite the interventions of scholars like Susan Wendell, Tom Shakespeare, and Margaret Price, there is still an understandably strong resistance in the field to discussing disability and suffering. What has happened, however, is that the experiences of becoming disabled for those who occupy multiple marginalized positions must be elided. For instance, to ask disabled black women "what happened" might reveal narratives like that shared in Assata Shakur's memoir, which reveals that she experienced a temporary physical disability, in the form of paralysis, and chronic illness as an effect of state violence. As Nirmalla Erevelles has argued elsewhere, disability is often the result of racialized socio-economic subjugation. In this paper, I analyze Assata Shakur's 1987 memoir, Assata: An Autobiography, as but one instantiation in a body of African American literature that links state violence to becoming disabled. I argue that Shakur uses her bodily fragility to bear witness to the violence the state executes against the U.S. marginalized communities.

Keywords: Black Disability Studies; Carceral Studies; Disability Studies; Black Feminism; Prison Literature

In May of 1973, Assata Shakur, along with Sundiata Acoli and Zayd Shakur, was stopped by state patrollers on the New Jersey Turnpike. ${ }^{1}$ What began as a stop for a supposed traffic violation ended with Zayd and state trooper Werner Foerster dead, and Shakur in critical condition. Assata and Sundiata were tried for Foerster's murder and Shakur convicted. Throughout her trial, Shakur, her legal team, and her supporters maintained (and continue to do so) Shakur's innocence; they argue that she was targeted by the FBI, a claim they feel has been substantiated since information about the FBI's COINTELpro became widely disseminated public knowledge. Moreover, Shakur's claim that she did not shoot and kill the trooper hinges on several points that bring together the intersections of race, gender, and disability. ${ }^{2}$ Evelyn C. White exclaims:

Indeed, apparently lost on the all-White jury who put her behind bars was the fact that ...Assata herself took two bullets.

One nearly ripped off her right arm. The other shattered her clavicle and remains lodged near her heart to this day. The jury gave short shrift to forensics experts who testified that Assata's massive injuries could have only been sustained with her hands in a position of surrender. They ignored the absence of gun residue on her fingers-there was no evidence she had fired a weapon.

\footnotetext{
${ }^{1}$ Throughout, I identify Assata Shakur and other black liberation fighters by their preferred names.

${ }^{2}$ While many disability studies scholars differentiate impairment, an injury, illness, or difference in bodily function, from disability, social or environmental barriers, I follow trends in disability studies that recognize that it is often difficult to separate impairment from disability and therefore use "disability" interchangeably with impairment.
} 
A forensic doctor analyzed Shakur's scars and x-rays, testifying that her injuries could only have been sustained if events happened how she claimed.

For Shakur and her supports, Shakur's injured body gives insight into "the truth" of what happened that night on the New Jersey Turnpike, a truth that situates Shakur as not just innocent of the crime for which she is accused but also a victim of the state troopers' racial profiling and violence. Consequently, in her 1988 memoir, Assata: an Autobiography, illness and disability emerge as a prominent yet underexamined aspect of her narrative and disabling violence central to her critique of the U.S. Reading Shakur's narrative as thus troubles critical and theoretical moves in disability studies to divorce disability from discourses of tragedy and suffering by underscoring how oppressive states exercise power through disabling violence. As scholars like Sharon Snyder and David T. Mitchell observe, scars, illness, and disability illicit a story, it "inaugurates interpretation" (6). Rosemarie Garland-Thomson writes, "By its very presence, the exceptional body seems to compel explanation, inspire representation, and incite regulation" (1). However, in disability studies, discussing the process of becoming disabled is often discouraged. It is not ok to ask "what happened" because it positions disability as an accident and otherwise undesirable (Adams 17-18). Instead, the field has sought to divorce disability from discourses about suffering, and rightly so, affirm disabled identity while challenging societal attitudes that devalue disabled life evident in obstacles such as environments inhospitable to disabled bodies. As Alison Kafer observes, "Although such positioning makes sense given the ableist context in which we live, it also circumscribes the stories we tell about ourselves to ourselves" (11). Despite the interventions of scholars like Kafer, there is still an understandably strong resistance in the field to discussing disability and suffering. Consequently, the narratives that disability studies, as a field, analyzes have been restrained. What has happened is that the experiences of becoming disabled for those who occupy multiple marginalized positions must be elided. Making space for narratives of tragedy and suffering, as Kafer suggests, "can potentially make more room for frank discussion of the effects of racism, settler colonialism, or classism in the field" (12). In the case of Assata Shakur, for example, allowing her story of disability, illness, suffering, and tragedy possibly means the difference between incarceration and freedom, erasure or acknowledgment of society's wrongs against her. Inviting the medical gaze and interpretation of her wounds enables her to create a narrative of her innocence. Her injury forecloses the possibility that she murdered the trooper while also proving that she could have been shot where she was only if she was in a position of surrender.

Moreover, after being shot, Shakur was rushed into spaces that exacerbated her injury. Lennox S. Hinds writes in his foreword to Shakur's autobiography:

She understates the awfulness of the conditions in which she was incarcerated ... In the history of New Jersey, no woman pretrial detainee or prisoner has ever been treated as she was, continuously confined in a men's prison, under twenty-four-hour surveillance of her most intimate functions, without intellectual sustenance, adequate medical attention, and exercise, and without the company of other women for all the years she was in their custody (xv).

Even though Shakur gives a conservative account of her experience in prison, in her autobiography it becomes clear how these conditions were debilitating, leaving her chronically ill, on top of her gunshot injury, during her time incarcerated.

Although the doctor's testimony is crucial to defense and healthcare reform is a subtheme of her work, Shakur's relationship to medicalization and the medical community is complex. Indeed, the prison clinic and the emergency room at the hospital are implicated in the state-sanctioned violence enacted against her. The collusion of law enforcement and medical practice is hardly unique in U.S. history-it's a frequent critique expressed by African American writers. Black activists and intellectuals have always placed health care as a crucial part of civil rights activism, and radical activism envisaged through the demand for health care is a legacy that the Black Panther Party for Self Defense continued (BPP). ${ }^{3}$ The BPP was intensely dedicated to medical activism. They opened free clinics; they made sickle-cell anemia a national conversation and political platform. They were very much aware of how the intersections of race and class shaped Black people's experience with health care, in primarily negative ways. Just as they were suspicious of the "pigs,"

\footnotetext{
${ }^{3}$ Medical histories such as W. Michael Byrd's and Linda A. Clayton's An American Health Dilemma (2000), which examines how historically race has shaped health care practice, have noted that activists from Martin R. Delany to Fannie Lou Harper to Dr. Martin Luther King, Jr. have argued for health care rights as human rights.
} 
they were also suspicious of white people who controlled and practiced medicine. ${ }^{4}$ While the Black Panther Party recognized that, like community protection, access to quality health care was crucial to Black people's liberation, they also believed that the white medical community, like the police, did not value Black life and used their knowledge and power to exact violence against the Black body. History reveals that they had good reason to be wary.

In 1972, details about the Tuskegee Syphilis experiment received national attention, ${ }^{5}$ followed three years later by details about the F.B.I.'s COINTELPRO operation-wherein the F.B.I., under the Hoover administration, was tasked "to expose, disrupt, misdirect, discredit, or otherwise neutralize the activities of black nationalist, hate-type organizations and groupings ..." (qtd in Carson 30). These events no doubt linked state violence and surveillance with medicine. Nevertheless, this part of the Black Liberation Movement's history is often subsumed and marginalized within other discussions or ignored altogether. ${ }^{6}$

Moments in Shakur's text stand out as key examples of that troubling history. Most of her experience as a political prisoner is also her experience as a patient. Consequently, her autobiographical relation of her six-year imprisonment, Assata: An Autobiography (1987), details the legal-medical abuses she sustained. Shakur's autobiography describes violent encounters with law enforcement and medical personnel putting their professional methods and status in the service of racial domination. Bodily vulnerability, particularly that of the female body, take center stage in her text. Therí Pickens in New Body Politics (2012) sets forth what's at stake: "within narratives by and about Blacks ... embodied experience, particularly when the body announces its fragility, becomes a vehicle through which they articulate their reflections on and critiques of the world we inhabit" (1). Shakur uses her corporeal fragility to bear witness to the violence these institutions jointly execute against the U.S. Black community. These violent encounters with authority signify Black people's status as disenfranchised citizens, and as infrahuman subjects of a racialized nation-state. This is not because injured Black bodies are metaphor for their status, per se, but because, as Jasbir Puar, among others, reminds us, Black people's dehumanization marks them as available for disablement (x).

At stake in my argument are narratives and conventions that would deny Black women their vulnerability and assailability. Prominent narratives of Black women as excessively strong ensures that experiences of illness, impairment, and disability as a result of state violence and neglect are suppressed. For instance, in light of more recent developments in political relationships with Cuba, Shakur has not only been catapulted back onto the FBI's most wanted list, but, in an article on the matter, constructed as a source of injury to the state of New Jersey. The article from N.J.'s The Record, is titled, "CHESIMARD REMAINS AN OPEN WOUND IN N.J." It is not only that Cuba continues to offer her political asylum but that Shakur refuses to be silent about matters. As the article states, "Chesimard ... continue[s] to receive the most attention, in part because ... [she has] continued to speak out in Cuba" (Kelley). Bearing witness to her experiences of violence as evidence of her innocence, proof her victimhood, and testament against the disabling practices of the U.S. is rhetorically constructed as an injury to the state. The article's metaphorical use of injury erases and suppresses the very real injury that Shakur sustained.

Shakur's narrative underscores the centrality of issues of illness and disability for conversations around state violence, particularly police brutality, and the prison industrial complex. Pivotal works that criticize the prison industrial complex, such as Michelle Alexander's The New Jim Crow (2010), tend to focus solely on how these conditions affect cisBlack men with little to no attention to disability or gender. My reading of Shakur's narrative through the lens of disability situates her story squarely within current conversations in disability studies such as Liat Ben-Moshe's work on disability and incarceration and, most recently, the critical interventions by contributors to the special issue of African American Review on Blackness and Disability, like Anna Mollow's article on police violence, disability, and fatness, that push back against this myopic focus.

\footnotetext{
${ }^{4}$ See Alondra Nelson's Body and Soul (2011) who provides the history of the Black Panther Party's medical activism.

${ }^{5}$ See James H. Jones whose Bad Blood (1981) chronicles the experiment and its aftermath.

${ }^{6}$ For instance, while there are numerous texts that detail and critique the Black Panther Party's history and political platform, such as The Black Panther Party: Reconsidered (1998), these texts do not elaborate in any detail on how Party members wrote about or experienced medical and, to a lesser extent, prison violence. Curtis Austin's Up Against the Wall (2006) reveals how Black Panther Party members were often subject to state violence, or acted violence against the state and each other, but it does not discuss how the Black Panther Party or individual Black Panthers dealt with medical violence, even though works works such as Alondra Nelson's Body and Soul (2011) would later outline how instrumental health-care rights activism was to the Black Panther Party and how the Black Panther Party positioned the white medical community as adversaries to Black People. Nelson's work gestures toward what this paper attempts to do: re-insert a political platform and position that has been marginalized in discussions about the Black Panthers. Unlike Nelson's book, however, this paper argues that these political activists thought that the medical community was more than just adversaries, they positioned the medical community as just as violent as the police.
} 


\section{Assata as Prisoner and Patient}

In Shakur's autobiography, race and gender, as it intersects with police brutality and the prison industrial complex, cannot be disentangled from the injured, ill, and disabled body. Her narrative situates both law enforcement and medical personnel as capable of violence in service of a white supremacist state. She demonstrates that both police violence and prison conditions affect the disabled and/as they disable.

Assata Shakur's autobiography opens with an act of disabling police violence:

There were lights and sirens. Zayd was dead. My mind knew that Zayd was dead. The air was like cold glass. Huge bubbles rose and burst. Each one felt like an explosion in my chest ... My chest was on fire. My blouse was purple with blood. I was convinced that my arm had been shot off and was hanging inside my shirt by a few strips of flesh. I could not feel it ... The medics examined me. I tried to talk, but only bubbles came out. I was foaming at the mouth (3).

The offices drag Shakur's seriously injured body across the ground, threaten her life, and deny her care as an interrogation tactic. The troopers not only continue this behavior once Shakur arrives at Middlesex County Hospital, but the hospital staff is also implicated in this violence and brutality:

THE HOSPITAL is glaring white. Everybody i see is white. Everyone seems to be waiting. All at once they are in motion. Blood pressure, pulse, needles, etc. Two detectives come in. I know they're detectives because they look like detectives. One of them has a face like a bulldog, with jowls hanging down the sides. They supervise the nurse as she cuts off my clothes. After a while, one of them dabs my fingertips with what look like Q-tips. Later i find out that this is the neutron activation test to determine whether or not $\mathrm{i}$ have fired a weapon. Another one then tries to fingerprint me, but he has trouble because my hand is dead. "Gimme the dead man's kit." He puts my fingers into spoonlooking things used to fingerprint dead people. They begin to ask me questions, but a bunch of doctors come in. One of them, who appears to be the head doctor, examines me. He pokes and prods, throwing me around like a rag doll. Then, like he is going to kill me, he jerks me around so that i'm on my stomach. The pain is like an electric shock. I moan. "Don't cry now, girlie," he says. "Why'd you shoot the trooper? Why'd you shoot the trooper?" I want to kick him in his face. I know he would kill me if he had the chance. I can see the scalpel slipping. One of the other doctors says something about calling the operating room. "Hell no!" is all i can think of. "Hell no!" (4)

Though Shakur's medical condition is precarious, police continue their investigation, and, as Cindy Au and Margo Perkins observe, continue their brutality while she is the emergency room. Analyzing this same scene, Au writes, "The violence of Shakur's experience at the hands of law enforcement describes a police force whose hands are hardly tied, and in fact whose dispensation of justice is tainted by emotion and vengeance. As various police come in and out of the hospital room where Shakur is being held, she hears one of the police threaten her life" (109-110). Similarly, Perkins notes: "Shakur's narrative...opens dramatically with the description of her violent capture on the New Jersey Turnpike. She recounts first the sensation of having been shot, and then the aggravation of her already precarious condition ... by further police aggression" (35). While Au and Perkins recognize and acknowledge the police officers' brutality in this scene, and Perkins even articulates some of the hospital staff's brutality-they withhold care and information about Shakur's medical status-neither scholar observes nor analyzes the explicitly violent actions of the medical staff in the scene. According to Shakur, it is the doctor who initially aggravates her injuries as he "pokes and prods" her; she fears the doctor will kill her if he has the chance. The doctor's interrogative shouts and condescending attitude towards Shakur's pain position him as just as angry and hateful towards her as the troopers who shot and arrested her. This scene not only describes, as Au argues, "a police force ... whose dispensation of justice is tainted by emotion and vengeance," but also a medical force "whose dispensation" of treatment is also "tainted by emotion and vengeance" (109).

Moreover, the hospital is a space of incarceration. The head doctor engages in violent interrogation tactics, "throwing [Shakur] around like a rag doll." Additionally, Shakur frames a Black nurse's attempt to follow in-take procedures as another effort to extract information for the cops and refuses to speak. When Shakur finally does relent and tell the nurse her name, in hopes of being able to then contact her family, her suspicions about the collaboration between the hospital staff and the police are confirmed: "Two minutes later the detectives are on [her] like white on rice" (Shakur 9). Though Shakur requests to call her mom and lawyer (who is also her aunt), she is denied. Isolated from family, friends, and her lawyer while seriously injured, 
Shakur has no way of caring for herself without the medical staff's aid. She is dependent on the very people who are indifferent, and often inimical, to her wellbeing. These circumstances also make Shakur easy to surveil. In the hospital, she is placed in a private room that allows troopers to watch her around the clock without disturbing the other patients. Shakur notes the irony of her predicament: the room in which she is housed represents medical care that is typically reserved only for wealthy whites:

I can't believe it. I have never imagined that hospitals have rooms like this. There is a sitting room, a huge hospital-equipped room (where i am kept), a den, a kitchen, a full bathroom and another little room whose purpose i will never learn. They transfer me to the bed and handcuff one of my legs to the side rail. I keep looking around. It is elegant and clearly for rich people. I am probably the first Black person who has ever been in this room. And the only reason i am there is for security. They have sealed off the doors and no one can enter except through the sitting room next door where three state troopers are stationed. Two regulars and one sergeant (8).

Nurses and doctors are often absent, so the troopers have access to her body, and "they get in their digs and bangs" (6). Even though a German nurse attempts to help Shakur, the police move her to another hospital. As Margo Perkins observes, "Her hospital room becomes a site of around-the-clock interrogation, harassment, and torture, which is alleviated only periodically by the entrance of sympathetic nursing staff" (35).

Presenting the hospital as a space of imprisonment, Shakur underscores her assertation that she "has never been free" (Shakur qtd. in Rolando), that imprisonment for Black people in the U.S. is a matter of degree. Shakur's rendering of the collusion between law enforcement and medical personnel, however, reflects what Liat Ben-Moshe describes as "trans-incarceration, or the move from one carceral edifice such as a psychiatric hospital to another such as a jail" (2). Ben-Moshe argues that, as the intellectually disabled were deinstitutionalized, they were merely transferred into other types of institutions, such as nursing homes and those spaces that were once institutions for the mentally disabled re-opened as prisons (3-4). Though these various institutions have significant differences (prisons supposedly promise due process, for instance, where psychiatric institutions do not), Ben-Moshe argues that they all operate "on similar logic" (5). "Incarceration," then, is "a continuum and not an isolated phenomenon that can be understood by engaging with only one locale" (Ben-Moshe 5). Ben-Moshe argues that recognizing this continuum should direct scholars and activists "into thinking more intersectionally about their interrelated nature" (5). Shakur, as an activist and intellectual, does precisely this work in her autobiography in her representation of the hospital as not just a temporary jail, but as also operating under the same logic of the criminal (in)justice system.

Shakur underscores the hospital emergency room as a space of trans-incarceration by paralleling her experience with emergency doctors to her experience with prison doctors. Shakur's time in prison is marked by similar exchanges with the medical community: guards injure her, prison conditions sicken her, she requests medical treatment and is denied or given inadequate care, or the medical community explicitly enacts physical or psychological violence against her. For instance, Shakur gets pregnant by fellow Black Liberation activist Kamau Avon White while both are locked outside of a trial. When she seeks prenatal care, she is met with hostility informed by racist and sexist myths. First, the prison doctor refuses to truly listen to her as she hints that she might be pregnant. He dismisses her complaints of symptoms that at one point "have her hanging on for dear life" (Shakur 122). Once he finally runs a blood test that reveals-to him because Shakur already knows-that she is pregnant, he withholds this information from Shakur and instead "makes fun of [her]" and "repeat[s] the same old stuff about a bowel disorder" and asks "some questions about [her] sex life" (122). In this instance, as with when she tried to find out about the extent of her injuries in the Middlesex County emergency room, she and the doctor engage in a struggle where medical information and the ability to withhold it is an act of power. Shakur eventually finds out from her aunt-lawyer, not her doctor, that tests confirm that she is pregnant.

In addition to withholding vital medical information, the prison doctor withholds care. After the court learns that Shakur is pregnant, she still does not receive adequate prenatal care and nutrition. When her body threatens to spontaneously abort (miscarry) and she seeks help from the doctor, he tells her, "Well, I can't force you to do anything, but my advice is to have an abortion. It will be better for you and for everyone else" (Shakur 126); however, when she asks if there is anything he can do to stop the miscarriage, or if he could call for a gynecologist, he refuses, insisting that abortion-"no matter which way [she has] it"-is best (126). Although the doctor claims that he cannot force her to act, by not offering treatment he does just this. Moreover, he not only shows no concern for her unborn child's life, but he also shows no concern for Shakur's life. He does not investigate why her body threatens to abort, an indicator of a potential health problem, nor does he care about the psychological impact a possible miscarriage will have on Shakur, who 
is already overwrought. His actions are violent against both her psyche and her body. Luckily for Shakur, the baby survives, and Shakur has her aunt petition the court to allow Dr. Garrett, a Black doctor affiliated with the Black Liberation Movement, to assume responsibility for her prenatal care. When she goes into labor, Dr. Garrett demands that the medical staff treat her humanely by unshackling her legs and actually providing proper care instead of ignoring her. However, once she delivers her baby girl and Dr. Garrett leaves, the medical staff resume treating her inhumanely by preventing her from practicing basic hygiene and making it difficult for her to nurse her newborn.

These moments not only parallel the general hospital emergency room and the prison hospital, underscoring Black people as perpetually imprisoned, the difference is degree, but also Shakur's experience with pregnancy, delivery, and motherhood also critically intervenes in, what until that point and still largely remains, a masculinist understanding of prison issues. As Mechthild Nagel argues, "Much mainstream reporting or prison literature ignores the gendered nature of prisons (and ignores writings by revolutionary prison intellectuals altogether)" (45). When Shakur is transferred to Rikers Island, the gendered nature of prison experience is brought into relief. For one, she highlights that women are subjected to intrusive and sexually violent searches. After being forced to publicly shower with special soap:

The last stage was the "search." Every woman who came into the building had to go through this process, even if she had been nowhere but to kourt. Joan Bird and Afeni Shakur had told me about it after they had been bailed out in the Panther 21 trial. When they had told me, i was horrified. "You mean they really put their hands inside you, to search you?" i had asked. "Uh-huh," they had answered. Every woman who has ever been on the rock, or in the old house of detention, can tell you about it. The women call it "getting the finger" or, more vulgarly, "getting finger-fucked." "What happens if you refuse?" i had asked Afeni. "They lock you in the hole and they don't let you out until you consent to be searched internally." I thought about refusing, but i sure as hell didn't want to be in the hole. I had had enough of solitary. The "internal search" was as humiliating and disgusting as it sounded. You sit on the edge of this table and the nurse holds your legs open and sticks a finger in your vagina and moves it around. She has a plastic glove on. Some of them try to put one finger in your vagina and another one up your rectum at the same time (Shakur 83).

Shakur's description of the procedure, while devoid of sensation and almost clinical, nevertheless reads as pornographic, linking it to sexual coercion and violence. In her narrative, sexual invasion and assault are built into the structure of prisons. In Shakur's interactions, medical staff is once again implicated, along with prison guards and the system, overall, in the humiliation:

Afterward, the guards had the nerve to tell me that a mistake had been made and a doctor would have to make a complete examination. I was just too disgusted. He was a filthy-looking man who looked more like a Bowery bum than a doctor. He coughed all over me without even covering his mouth, and his fingernails looked like he had spent the last five years in a coal mine. The only good thing about him was that he was quick. He rattled diseases off like he was an auctioneer and asked me if i had had them. Then he gave me a one-minute examination, took my blood, and that was it (84).

Under the auspices of "health," Shakur is subject to a gendered violation of her person, revealing the particularly experiences of women in prison. Shakur's interaction with law enforcement and medical personnel are always framed within the lenses of race, gender, class, and disability. For instance, Shakur's first observations when she is initially transferred to Rikers Island to stand trail for a burglary charge is that, "[The inmates] were all Black or Hispanic ... Some of the women were bloated, with swollen hands and feet. A few had a real strange look about them. One sat in a chair, her eyes crusted with sleep, giggling quietly to herself" (85). Incarceration is not just an issue that affects Black and brown women, but disabled women, too. She further speaks to issues of trans-incarceration when she learns that she is the section for people "who have infractions or for crazy people" (86). Shakur's narrative draws our attention to not only the over-representation of racialized women in prison, but also to disabled women, a conversation that is only beginning to garner critical and activist traction through the works of scholars like Ben-Moshe and activists like Talila Lewis and Leroy Moore. ${ }^{7}$

\footnotetext{
${ }^{7}$ Talila Lewis is an advocate and activist for the writes of black Deaf people wrongfully incarcerated, and Leroy Moore is a Black, disabled hip-hop artist and activist who brings social awareness on issues police brutality, particularly against black people with disabilities.
} 
As discussed, Ben-Moshe reveals how prisons become new sites of confinement for those formally warehoused in institutions for the disabled. Moreover, as Nagel notes, the image of Shakur with her hands raised above her head jettisons us into our current socio-political moment and the common protest cries of "Hands Up, Don't Shoot" (44), which directs our attention toward the intersections of state-violence, Blackness, and disability that is at the heart of the Black Lives Matter movement. Emmitt H. Thrower and Leroy Moore's heartwrenching documentary Where is the Hope: The Art of Murder-Police Brutality \& Disability Documentary (2015) candidly discusses (and displays) acts of police violence against disabled (mostly Black) people like Deborah Colbert, a mentally disabled Black woman who was fatally shot by California police in April of 2013 (Thrower). Indeed, as Where is the Hope captures Senator Dick Durbin (D-IL) stating, more than half of police shootings involve someone with a disability even though people with (mental) disabilities are not more violent than the able-bodied/minded but are more likely to be victimized (Thrower). The contributors to the recent special issue on Blackness and disability in African American Review elucidate these connections. Particularly salient to Shakur's narrative is Anna Mollow's article "Towards a Fat Black Disability Studies." Here, Mollow argues,

that fatphobia is routinely deployed in ways that exacerbate the problem of state-sanctioned violence against African Americans. As we shall see, antifat prejudice, racism, and ableism intersect to create a double bind in which black people are depicted as unvictimizable for two contradictory reasons: black people-of all sizes, but fat black people in particular-are figured as innately disabled but also as invulnerable to disability, injury, or suffering (105).

Cindy Au suggests that police and journalists relied on a discourse of pathology and monstrosity to criminalize Shakur as the "soul" and "mother hen" of the supposedly murderous Black liberation army (110). This monstrosity not only gestures towards mental disability but has embodied connotations. For example, Shakur recreates the following conversation with a female inmate at Riker's:

"Yeah," Coke said, "I saw your picture on TV, but you look different now." "How?" i asked. "When I saw your picture I thought you was much bigger. And much blacker, too." "Really?" I laughed. It was a statement i heard over and over. Everybody told me they thought i was bigger, blacker, and uglier. When i asked people what they thought i looked like, they would describe someone about six feet tall, two hundred pounds, and very dark and wild-looking. "Bad as them papers said you was, I just knew you had to look bad. And here you are, just a little ole thing" (87).

This conversation exemplifies Mollow's arguments about fatness, Blackness, and criminality. Though Shakur is a petite and thin woman, ableist, fatphobic conceptualizations of the criminalized Black body and the double-bind of being always already disabled but incapable of vulnerability are precisely the narratives circulated about Shakur against which she must write. To push back against this double-bind, Shakur emphasizes her bodily fragility and vulnerability, yet displays anxiety over disability.

As I have argued, injury, illness, disability are central themes in the text. Part of how these themes operate is through Shakur's anxiety about disability. At the beginning of her autobiography, after she is shot but before she is transported to the hospital, Shakur thinks, "If i live ... i'll only have one arm" (4). She continues to articulate this fear of losing her arm once she is in the hospital, as she responds in silence to the Black nurse's attempts to collect information. Shakur writes, "I drift off, thinking about my arm. It is still there" (5). Shakur's concern over her arm becomes obsessive, especially considering at this point in the plot she does not yet know whether she will live or die. Her arm, within the story and as a narrative device, comes to symbolize a wholeness that police brutality and violence threatens to shatter. To lose her arm, it seems, would be the equivalent of embodying the monstrosity that they have attributed to her character.

Shakur's anxiety over losing her arm continues until the end of the narrative. For instance, towards the end of her autobiography, Shakur describes the following scene:

I'm being introduced at a party. The hostess tells me that the man is from El Salvador. I hold out my hand to shake his. A few seconds too late, i realize he is missing an arm. He asks me what country $\mathrm{i}$ come from. I'm so upset and ashamed i'm almost shaking. "Yo soy de los estados unidos, pero no soy yankee," i tell him. A friend of mine had taught me that phrase. Every time someone asked me where i was from i cringed. I hated to tell people i was from the u.s. I would have preferred to say i was New Afrikan, except that hardly anyone would have understood what that meant. When i read about death squads in El Salvador or the bombing of hospitals in Nicaragua, i felt like screaming (268). 
The man's missing arm recalls Shakur's experience with police violence and the resulting disabling injury that nearly disfigured her body. Rather than react with recognition, however, she is embarrassed. Shakur's reaction to the El Salvadorian man's one-armness seems to exemplify Ato Quayson's arguments in Aesthetic Nervousness: Disability and the Crisis of Representation (2007). Quayson argues that there "is [an] implicit assumption that disability is an "excessive" sign that invites interpretation, either of a metaphysical or other sort" (14). He continues:

Following from this first point is the issue of subliminal fear and moral panic. Several disability scholars have already noted the degree to which the disabled body sharply recalls to the nondisabled the provisional and temporary nature of able-bodiedness and indeed of the social frameworks that undergird the suppositions of bodily normality. I will suggest, however, that in literature this subliminal unease manifests itself within the structures of the literary discourse itself, generating a series of crises in the protocols of representation. Finally, I want to highlight the degree to which the social treatment of disability has historically been multifaceted and sometimes even contradictory (14).

One-armness is an "excessive sign" in Shakur's autobiography that consequently begs interpretation. Moreover, Shakur's unease with the man's one arm is a reminder of the temporarily and precariousness of her own visibly able-body. Part of her thesis is that, as a Black woman, the state can maim and injure her body with impunity. However, this is where Shakur's employment of disability as a trope complicates Quayson's arguments. Shakur's temporary paralysis in her arm and the Salvadorian man's one arm invite interpretations grounded in the material. Shakur's arm is evidence of police brutality against Black people in the U.S. and the corruption of the criminal justice system. The man's one arm signifies U.S.-sanctioned violence in El Salvador and Nicaragua, violence that Shakur, as a U.S. citizen, exiled as she may be, feels implicated in. Violent encounters with authority signify their status as disenfranchised citizens, and as infrahuman subjects of a racialized nation-state.

As Therí Pickens argues in New Body Politics (2012), "within narratives by and about Blacks ... embodied experience, particularly when the body announces its fragility, becomes a vehicle through which they articulate their reflections on and critiques of the world we inhabit" (1). Shakur's injured body and the El Salvadorian man's disabled body are synecdoches for the communities oppressed by U.S. violence. Disability represents something other than itself; it is a negative metaphor aligned with tragedy and violence that potentially further devalues disabled lives. Disability is also, however, an actual consequence of state violence. Understanding the dual function of disability as metaphor and reality is crucial for analyzing Shakur's critique of U.S. violence.

Shakur tries to separate herself from her U.S. citizenship, and her possible implications in U.S. violence. In the scene with the El Salvadorian man, she tells him "Yo soy de los estados unidos, pero no soy yankee" (Shakur 268). Her autobiography, as a whole, attempts to counter the persona of her crafted by police and mainstream journalists. Consequently, as Au argues, "By the time Shakur pens her life story, two distinct Assatas exist-the monster woman of the media, and the political activist she brings to life through autobiography" (104). Two Assatas exist within the autobiography itself. Even as Shakur centers her experience with bodily fragility, she attempts to divorce herself from it. As Quayson argues, the anxiety the able-bodied experience in the face of disability "manifests itself within the structures of the literary discourse itself, generating a series of crises in the protocols of representation" (14). Shakur uses the aesthetic flexibility of life writing to make formal decisions that allows her to navigate fraught and often contradictory politicized narratives about violence and Black bodies. Moreover, as Carol Henderson argues, prison life writing often works to "... reclaim ... [the sick and injured] body discursively in order to facilitate a counter-discourse that re conceptualizes the meanings of literal and figurative bodies within certain predetermined social structures" (13 original emphasis). Shakur re-claims and re-conceptualizes narratives ascribed and inscribed on her body when she dissociates from her vulnerable body and instead constructs an able one. As a result, the whole, cohesive autobiographical self does not emerge within Shakur's text. Instead, she manipulates her discursive body to construct and test multiple personas.

In Assata, Shakur represents her imprisoned body as almost always disabled, injured, or sick and she represents her childhood body as almost always well and able. She never describes moments of sickness or injury as she relates the details of her upbringing and coming into political consciousness. Her activist experience, as I've discussed, is chronicled by disability (she is temporarily paralyzed), injury, and illness. The effect is that she aligns her injured, pained, and abused body to her identity as the Black Liberation fighter suspected of murder and burglary, and she aligns her whole and healthy body to a version of herself that never loses her 
voracious appetite for art, who still loves to read, and who is able and is willing to be a mother to her daughter. The narrative achieves this by moving back and forth through time; chapters alternate between creeping onward, and away from, the events of the immediate present, and racing forward through events from the past, until the two almost meet. For instance, the first chapter begins with the police shooting and her hospitalization, and the second chapter begins with her childhood in the South. The chapters then alternate back and forth between past and present, imprisoned and injured, healthy, free, and whole until Chapter 18, where the two narratives not quite chronologically "meet." The effect is that two personas emerge: the militant activist who is incarcerated, beaten, and nearly broken, and who "The FBI [can't] find any evidence ... was born" (Shakur 18), and the vibrant, curious subject of a Bildungsroman who is fast-tracking towards the other's destiny but is not yet shackled to it. The two personas' fates never fully intersect; the one never emerges into the other. Instead, both destinies are abruptly foreclosed. The Bildungsroman ends with Shakur underground, presumably before the events that open the autobiography since Shakur never shares her version of what happened to the state trooper. While chapters eighteen to the postscript continue to chronicle the remainder of Black Liberation Leader Shakur's trial, the prison-narrative abruptly ends, too. With only a page break, the narrative leaps from Shakur's dead-end, hopeless life incarcerated in the U.S. to a completely other experience as free in Cuba. Once again, both for reasons one can surmise as legal and also due to her desire to protect other activists, Shakur never shares how she escapes and eventually makes her way to Cuba.

The persona that lives-out and embodies this new destiny does not seem to be a synthesized version of the prior identities. The version of herself on which the narrative ends, the aspects of her former self she still can and wants to claim, is precisely what prison and revolutionary work foreclosed: the maternal, familyoriented Assata. Shakur constructs a final persona that reclaims what was before lost to her: "We were here together ... my small little family, holding each other after so long" (274).

\section{Conclusion}

To ask Assata Shakur "what happened," to welcome Shakur's story of becoming temporarily disabled and experiencing illness, is to ignite a powerful critique of the prison system and medical community as partners in crime. Shakur's narrative, read for the intersecting issues of illness/disability, violence, and imprisonment reveals that even so-called neutral spaces such as the hospital emergency room easily transforms into what Liat Ben-Moshe describes as a "force of trans-incarceration." This is not to equate the (general) hospital with prison, nursing homes, or psychiatric wards (although general hospitals do contain such locations of confinement), but to demonstrate how state power can easily manipulate such spaces into auxiliaries in its violent exercise of biopower as they temporarily embody the purpose of confinement. Noticeably, though Shakur directs her attention toward her sick and injured body, it is not the primary cause of her suffering. Indeed, analyzing and interpreting interactions and relationships that foreground the sick and injured body in Shakur's autobiography direct our attention away from the body and forces us to see that although society positions the prison system and medical community as institutions that improve public welfare, they, in fact, have been frequently used to enact violence as a means to control a people criminalized yet fighting to be free.

Mia Bay argues that slavery and the struggle to maintain white supremacy was a "war of minds" (7). While Shakur's narrative seems to confirm this, it also suggests that the struggle over the mind is waged against and through the Black body. The bloodied, bruised, and beaten body in Shakur's narrative represents not only the literal struggle against very real and threatening social institutions but also the struggle to discursively claim and define herself against the way the world defines her. Asking "what happened?" carves a creative space where Shakur can define herself, narrate the contours of her identity where the exercise of laying claim to the story of her body is akin to laying claim to her freedom.

\section{Competing Interests}

The author has no competing interests to declare.

\section{References}

Adams, Rachel, et al., editors. Keywords for Disability Studies. NYU Press, 2015.

$\mathrm{Au}$, Cindy. Media, Manipulation, and Self-Fashioning: Black Power Women's Autobiography and Public Perception. Madison: The University of Wisconsin, 2010. ProQuest, https://search-proquest-com.proxy. libraries.smu.edu/docview/755704212/abstract/6057E8C228DB4948PQ/1.

Austin, Curtis J. Up Against the Wall: Violence in the Making and Unmaking of the Black Panther Party. Fayetteville: U of Arkansas P, 2006. Print. 
Bay, Mia. The White image in the Black Mind. New York and Oxford: Oxford UP, 2000. Print.

Ben-Moshe, Liat. "Disabling Incarceration: Connecting Disability to Divergent Confinements in the USA." Critical Sociology, vol. 39, no. 3, May 2013, pp. 385-403. CrossRef. DOI: https://doi. org/10.1177/0896920511430864

Byrd, W. Michael, and Linda A. Clayton. An American Health Dilemma: Volume One A Medical History of African Americans and the Problems of Race: Beginnings to 1900. New York and London: Routledge, 2000. Print.

Carson, Clayborne, David Gallen, and Spike Lee. Malcolm X: The FBI File. Skyhorse Publishing Inc., 2012.

Emmitt, H. Thrower. Where Is Hope: The Art of Murder - Police Brutality \& Disability Documentary. YouTube, www.youtube.com/watch?v=x7vkAL_d87g. Accessed 1 Feb. 2018.

Garland-Thomson, Rosemarie, editor. Freakery: Cultural Spectacles of the Extraordinary Body. New York University Press, 1996.

Henderson, Carol E. "Writing from No Man's Land: The Black Man's Quest for Freedom from behind the Walls." From the Plantation to the Prison: African American Confinement Literature. Ed. Tara T. Green. Macon, GA: Mercer UP, 2008. Print.

Jones, James H. Bad Blood: The Tuskegee Syphilis Experiment. New York: Free Press, 1981. Print.

Kafer, Alison. "Un/Safe Disclosures: Scenes of Disability and Trauma." Journal of Literary \& Cultural Disability Studies, vol. 10, no. 1, Mar. 2016, pp. 1-20. DOI: https://doi.org/10.3828/jlcds.2016.1

Mitchell, David T., and Sharon L. Snyder. Narrative Prosthesis: Disability and the Dependencies of Discourse. University of Michigan Press, 2001. DOI: https://doi.org/10.3998/mpub.11523

Mollow, Anna. "Unvictimizable: Toward a Fat Black Disability Studies." African American Review, vol. 50, no. 2, 2017, pp. 105-121. DOI: https://doi.org/10.1353/afa.2017.0016

Nagel, Mechthild. "Three: Angela Y. Davis and Assata Shakur as Women Outlaws: Resisting U.S. State Violence 1." Wagadu: a Journal of Transnational Women's and Gender Studies, vol. 13, 2015, pp. 43-78.

Nelson, Alondra. Body and Soul: The Black Panter Party and the Fight Against Medical Discrimination. Minneapolis and London: U of Minnesota P, 2011. Print. DOI: https://doi.org/10.5749/minnesota/ 9780816676484.001.0001

Perkins, Margo V. Autobiography as Activism: Three Black Women of the Sixties. Jackson, MS: UP of Mississippi, 2012. ProQuest ebrary. Web. 4 November 2015.

Pickens, Therí A. New Body Politics: Narrating Arab and Black Identity in the Contemporary United States. New York and London: Routledge, 2014. Print. DOI: https://doi.org/10.4324/9781315819310

Puar, Jasbir K. The Right to Maim: Debility, Capacity, Disability. Duke University Press Books, 2017. DOI: https://doi.org/10.1215/9780822372530

Quayson, Ato. Aesthetic Nervousness: Disability and the Crisis of Representation. Columbia University Press, 2007.

Rolando, Gloria. The Eyes of the Rainbow. Documentary, 1997.

Shakur, Assata. Assata: An Autobiography. Westport, CT: Lawrence Hill \& Company, 1987. Print.

The Black Panther Party: Reconsidered. Ed. Charles E. Jones. Baltimore: Black Classic Press, 1998. Print.

White, Evelyn C. "Prisoner in Paradise: An Interview with Assata Shakur." Blacklight, 2013, www. blacklightonline.com/a_shakur.html.

How to cite this article: Hinton, A 2019 A War of Minds Waged Against Bodies: The Political Activist as Prisoner and Patient. Anthurium, 15(2): 5, 1-10. DOI: https://doi.org/10.33596/anth.380

Published: 23 September 2019

Copyright: ( $) 2019$ The Author(s). This is an open-access article distributed under the terms of the Creative Commons Attribution 4.0 International License (CC-BY 4.0), which permits unrestricted use, distribution, and reproduction in any medium, provided the original author and source are credited. See http://creativecommons.org/licenses/by/4.0/. 